\title{
Evaluation of carbapenem inactivation method for accurate detection of pseudomonas aeroginosa isolates producing carbapenemase enzymes
}

\author{
Beig $\mathbf{M}^{1}$, Arabestani MR \\ 1. MSc of Medical Microbiology, Depatment of Medical Microbioloy, Faculty of Medicine, Hamadan University of Medical Sciences, \\ Hamadan, Iran. ORCID ID: 0000-0003-1243-3164 \\ 2. Associate Professor of Medical Bacteriology, Brucellosis Research Center, Hamadan University of Medical Sciences, Hamadan, Iran \\ (Corresponding author), Tel: +98813838077, Email: mohammad.arabestani@gmail.com, ORCID ID:0000-0001-9991-8193
}

\section{ABSTRACT}

Background and Aim: Different phenotypic methods are available for identification of pseudomonas aeroginosa isolates producing carbapenemase enzymes. Carbapenem inactivation method (CIM) is a fast and inexpensive way for detection of this enzyme. The purpose of this study was to evaluate the CIM method for accurate identification of carbapenemase producing pseudomonas aeruginosa isolates.

Materials and Methods: A total of 97 clinical specimens were collected from the patients in the hospitals of Hamadan from November 2017 to May 2018, in Iran. Antibiotic susceptibility test was performed by disc diffusion method. Minimum inhibitory concentration (MIC) for imipenem was measured by E-test. Then, CIM test and polymerase chain reaction (PCR) methods were performed. Sensitivity, specificity, positive predictive value (PPV) and negative predictive value (NPV) of the CIM test were calculated for each of the genes. Using SPSS16 software, significance of CIM test was evaluated by chi-square test (X2).

Results: In this study, the highest and lowest levels of resistance belonged to cefoxitin 91 (93.8\%) and piperacilin/tazobactam 38 (39.2\%). Among 97 P. aeruginosa clinical isolates, 49 (50.51\%) were carbapenemase producer with positive results for CIM test in $44(89.7 \%)$ isolates, and negative results for CIM test in 48 (49.48\%) isolates. Therefore, the sensitivity and specificity of the CIM test were $90 \%$ and $100 \%$, respectively.

Conclusions: According to the results of this study CIM method is an inexpensive test which can be easily performed and has high sensitivity and specificity for identification of carbapenemase producing $P$. aeruginosa isolates.

Keywords: Pseudomonas aeruginosa, PCR, CIM

Received: Feb 3, 2019

Accepted: July 14, 2019

How to cite the article: Beig M, Arabestani MR. Evaluation of carbapenem inactivation method for accurate detection of pseudomonas aeroginosa isolates producing carbapenemase enzymes. SJKU 2019;24(4):103-115.

Copyright (C) 2019 the Author (s). Published by Kurdistan University of Medical Sciences. This is an open access article distributed under the terms of the Creative Commons Attribution-Non Commercial License 4.0 (CCBYNC), where it is permissible to download, share, remix, transform, and buildup the work provided it is properly cited. The work cannot be used commercially without permission from the journal. 


\section{بررسى روش غيرفعال كردن كاربإنم جهت تشخيص دقيق ايزولههاى سودوموناس آئروثينوزا مولد آزيمهاى كاربإنماز}

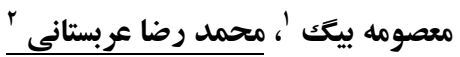

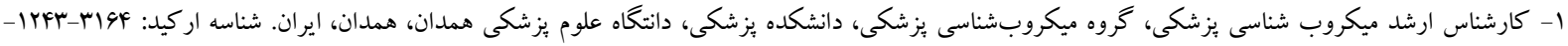

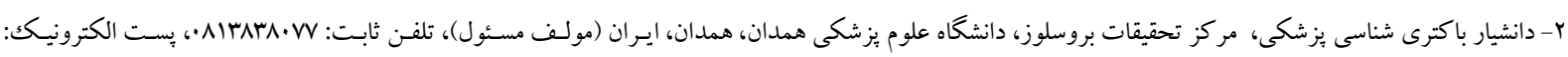

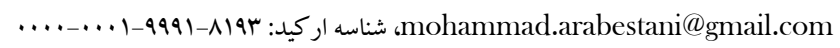

جـكيله زمينه و هدف: جهت شناسايى ايزوله هاى سودوموناس آئروثينوزا مولد آنزيم كارباينماز، روشهاى فنو تييى مختلفى وجود دارد.

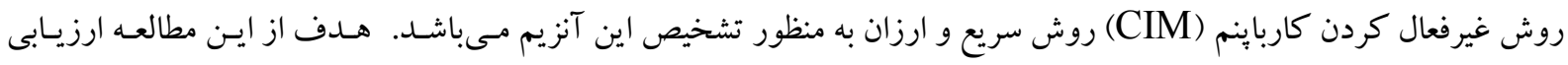
روش CIM براى شناسايى دقيق ايزولههاى سودوموناس آئروزينوزا مولد آنزيمهاى كارباينماز مى بـاشد.

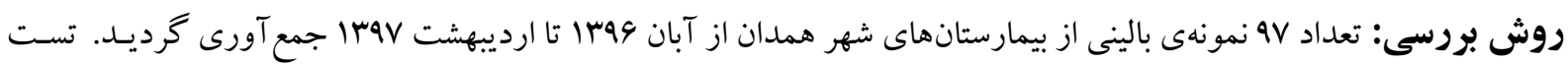

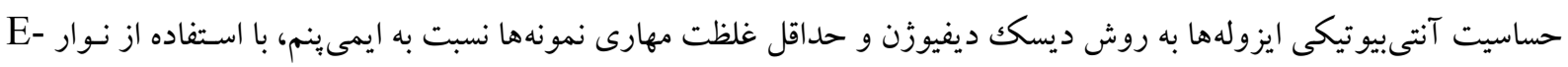

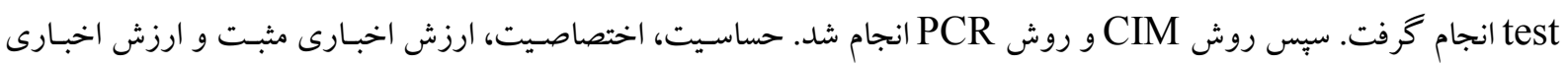

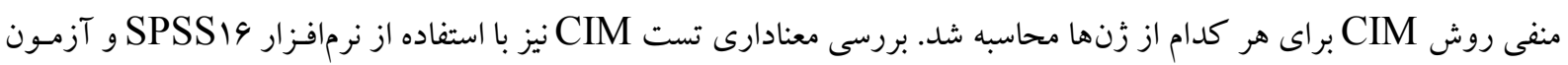
آمارى كاى دو (X)

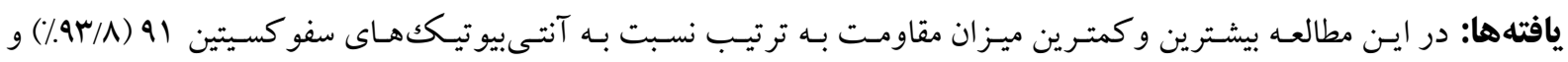

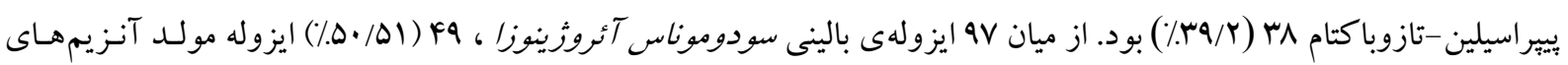

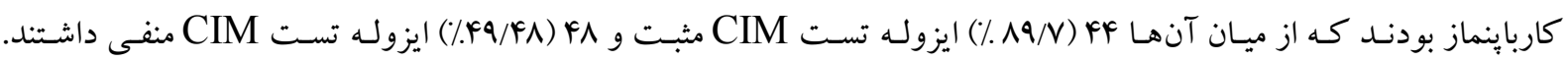

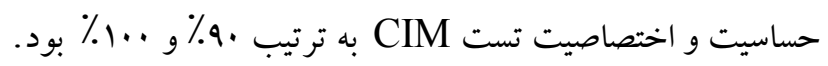
نتيجه كيرى: نتايج اين مطالعه نشان داد كه روش CIM يكك روش ارزان و آسان و داراى حساسيت و اختصاصيت بـالايى بـراى

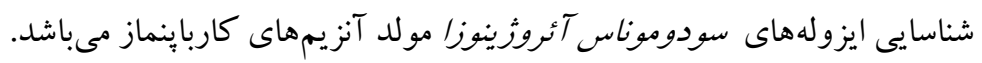
كليد وازه ها: سودوموناس Tئروثينوزا، PCR

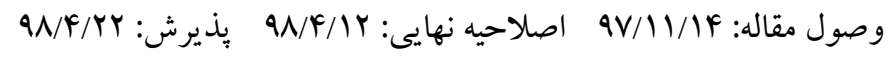


بوسيلهى كلاو لانيك اسيد و تازوبا كتام مهار مسىشوند (ه). Klebsiella pneumoniae carbapenemase

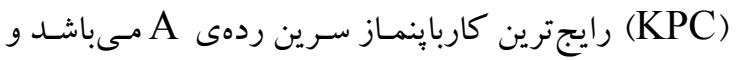

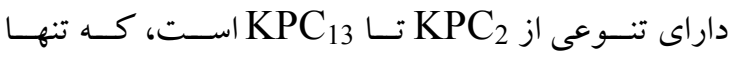
درتوالىهاى آمينو اسيدى تفاوت دارند (9). زن أن

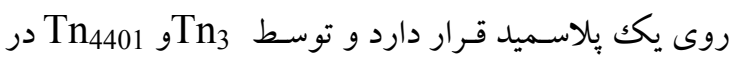

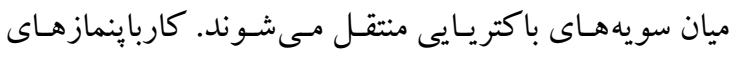

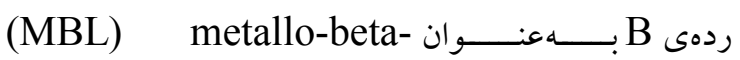
lactamase شناخته مى شوند كه در جايگاه فعاليـت آنهـا روى وجـود دارد (V). متـالو بتالاكتامازهـا بـه دليـل ايجـاد

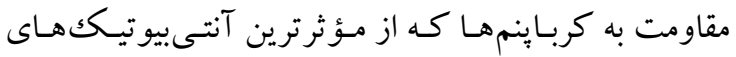
مورداستفاده عليه عفونت هـاى سو دوموناسى هسـتند، بسـيار

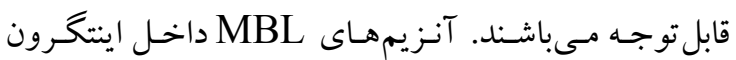
واقع شده و توانايى ادغام در بِلاسميد يا كروموزوم را دارنـــ

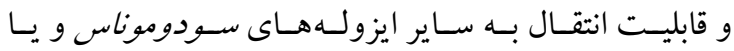

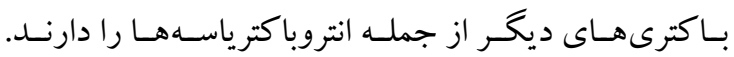
متالوبتالاكتامازها بر اساس ساختار مولكولى به انواع مختلفى

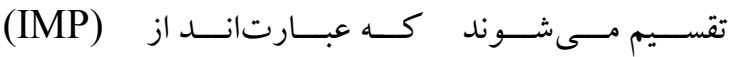

Veronaimipenemase ،Imipenemase metallo-German imipenemase ،(VIM) ,(SPM) Sao Paulo beta-lactamase ,(GIM) ,(NDM) NewDelhi metallo-beta-lactamase كــــــ از ميــان ابــن SIM) Seoul Imipenemase آنزيمها، IMP در سودوموناس آئروزينوزا بارزتر مىباشد . ردهى C به آنزيمهاى AmpC معروف هستيتد و قـادر بـه هيدروليز سفومايسين هـا و سفالوسيورينهـا مى باشـند (1). دستهاى از بتالاكتامازهاى سرين نيز وجـود دارنــ كـه تشـابه انـدكى بـا بتالاكتامـازهـاى ردمى A و C دارنــد و تحـت

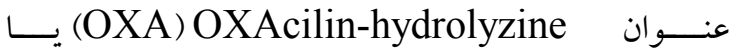
اخزاسيلينازها نام گذارى مىشوند. اين بتالاكتامازها در ردهى

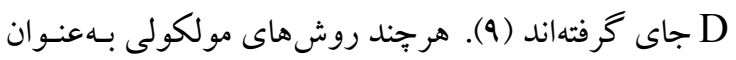
روشهاى مرجع براى شناسايى ايزوله هـاى مولـد كارباينمـاز

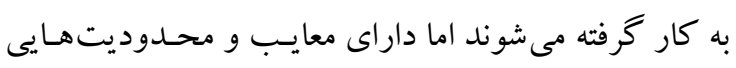

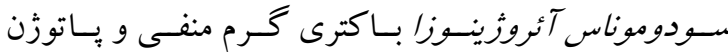
فرصت طلبى است كه عفونتهـاى مختلفى در افراد داراى

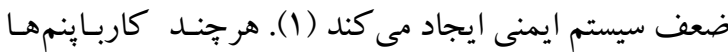

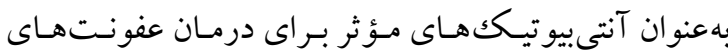

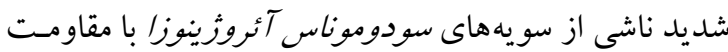
دارويى جند گانه باقىماندهاند، اما افزايش ميزان مقاومت به اين آنتىبيو تيككها

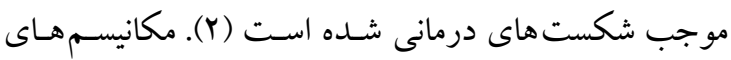

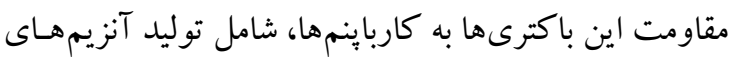

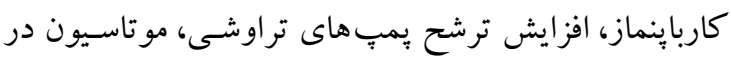

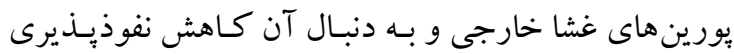

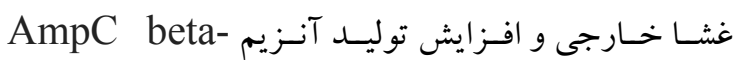
(AmpC) lactamases مكانيسمهاى مقاومت نسبت به اين رده از آنتىبيو تيككهـا،

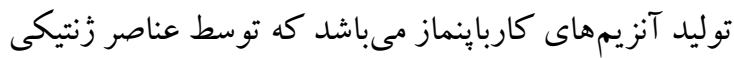

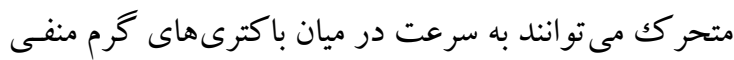
به ويزه سودوموناس آئروزينوزا منتقل شده و موجب انتقال مقاومت شوند (r). براى طبقهبندى بتالا كتامازهـا روشهـاى

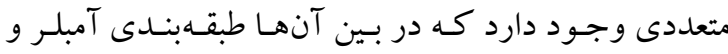
طبقهبندى بوش كاربرد بيشترى دارند. در طبقهبنـدى آمبلـر

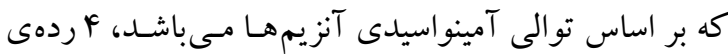

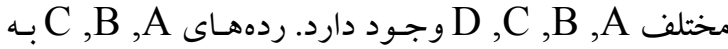
وسـيلهى مكانيسـم سـرين عمـل مسى كنـــ، درصـورتى كـهـ ردهى B براى فعاليت خود نيازمند عنصر روى مىباشد (F). كارباينمازهاى ردهى A A يك سرين بتالاكتاماز هستـند كـه در جايگاه فعال آنها سرين وجود دارد و براى فعاليت خهود نيازمنـد سـرين مسباشـند. كاربإينمازهـاى ردهى A B, B توالى آمينواسيدى خيلى شبيه به هم دارنــ. تشـابه سـاختارى ميان اين سه كلاس تا اندازه اى است كه مى توان آنها را از يكك نياى مشترك دانست. ايـن آنزيمهـا توانيايى هيـدروليز

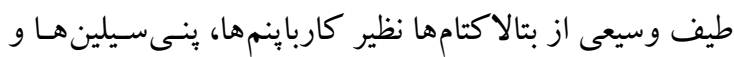
آزترونام را دارا مىباشند. كارباينمازهـاى ردمى A C 
تست اكسيداز مثبت، كاتالاز مثبت، واكنش در محيط ترييل شو كر آيرون آكار به صورت قليا/قليا، تست اكسيداسيونفرمانتاسيون بـه صسورت اكسيداسيون مثبـت و فرمانتاسيون

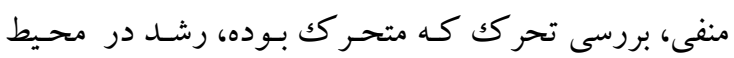

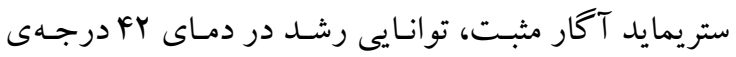

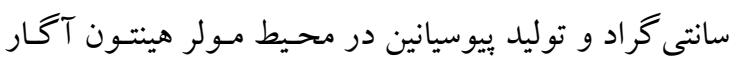

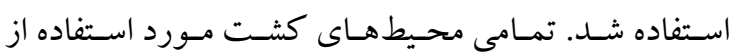
شر كت مركى كشور آلمان خريدارى شدند (If). تست حساسيت آنتىبيوتيكى مقاومت آنتى بيوتيكى ايزوله ها، به روش استاندارد ديسيك

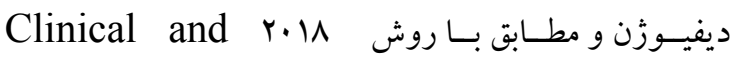
(CLSI) Laboratory Standards Institute كرفت (ه) (ه ديسك هاى آنتىبيو تيكى از شركت MAST

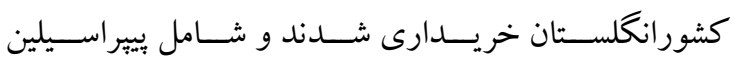

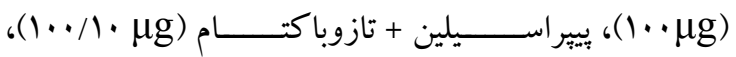

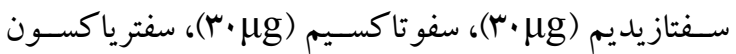

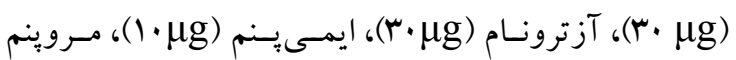

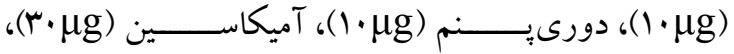

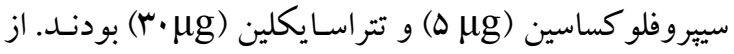

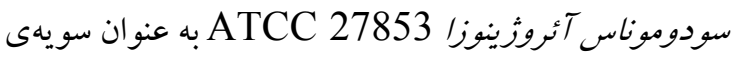
كنترل استفاده شد، كه از موسسهى تحقيقاتى انستيتو ياستور كشور ايران خريدارى شد (19).

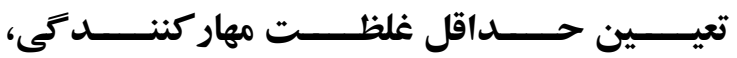
MinimumInhibitory Concentration ايمى ينم (MIC) در اين روش حداقل غلظت مهار كنندگى براى ايمسي يـنم بـا

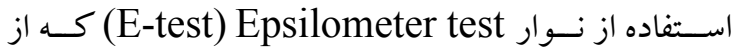
شـر كت MAST كشـور انغكلسـتان خريسـارى شـد، انجـام كرفت. به اين صورت كه ابتدا سوسبانسيون نيم مـك فارلند

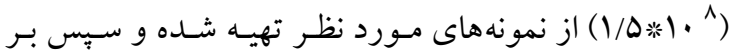
سطح محيط مولر هينتون آكار به صورت جمنى كثـت داده شد، بس از جند دقيقه نوار E-test ايمىينم بر سطح بليست قرار گرفت و بـه مـدت NF-1
هم جون هزينـهى بـالا، نيازمنـدى بـه افر اد متخصص، عـدم

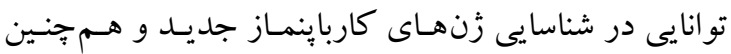
محدوديت در بـه كـار گيرى ايـن روش در آزمايشـاهــاى بالينى مى باشند. تست هـاى فنوتيبى مختلفى بـا حساسيت و اختصاصيت متفاوت بـراى شناسـيى آنزيمهـاى كارباينمـاز وجود دارد (·(). تست Carbapenem Inactivation (CIM) Method تستهاى فنوتييى مناسب جهت شناسايى جنين سويههايى

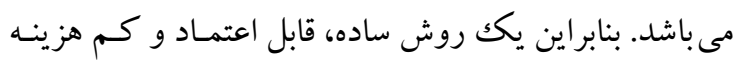

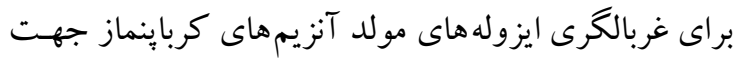

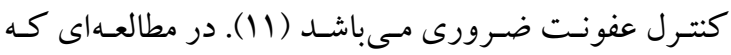

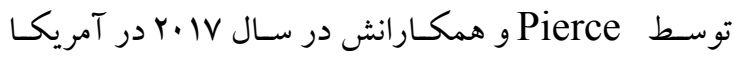

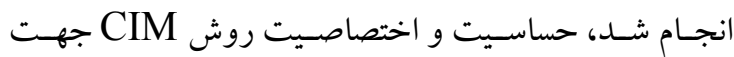

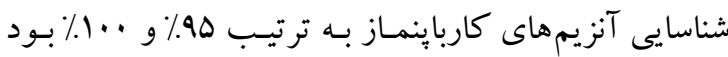

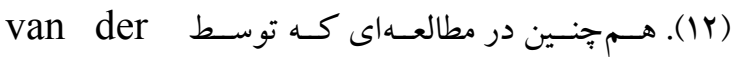

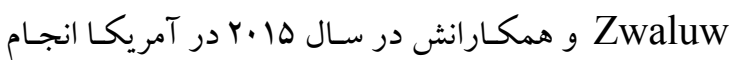

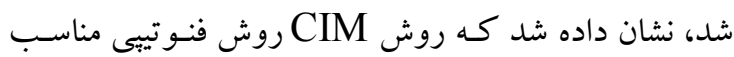

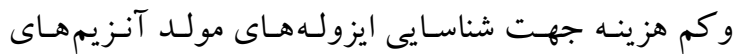
كاربإينماز مى باشد، كه حساسيت و اختصاصيت بالاى تست را نشان مىدهد (rا). لذا هدف از اين مطالعه ارزيابى CIM روش CIM جهت شناسايى سريع ايزوله هاى سـودوموناس آئروثينوزا مولد آنزيمهاى كاربإينماز مىباشد.

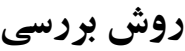 جمع آورى ايزولههاى باكتريايى}

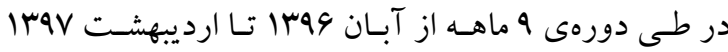
نمونسهــاى باكتريـايى سـودوموناس آئروزينسوزا از بيمـاران بسترى در بخشهاى مختلف بيمارستان هاى بعثت، بهشتى و

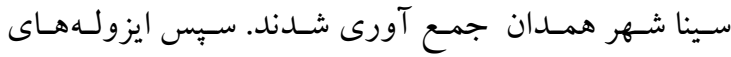
باكتريايى به آزمايشگاه ميكروب شناسى دانشكده يز شـكى منتقل شدند. جهت تأييد ايزوله هاى سودوموناس آئروزينوزا

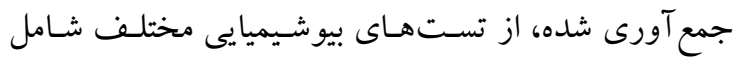

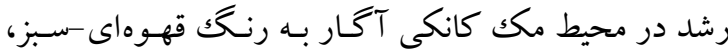




\section{DNA استخراج}

در اين مطالعه استخراج DNA بـه روش جوشـاندن انجـام

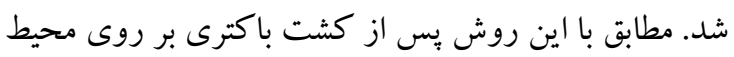

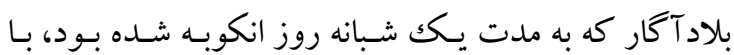

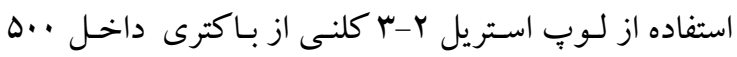

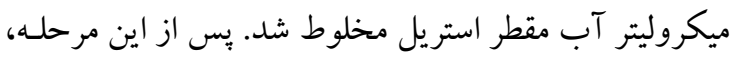

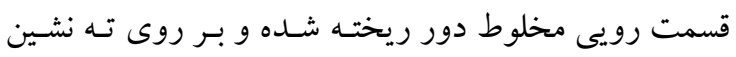

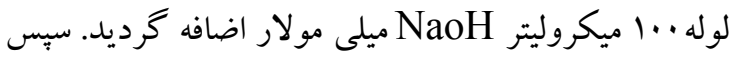

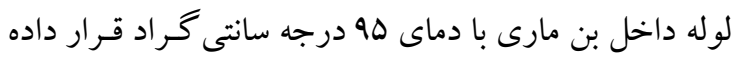

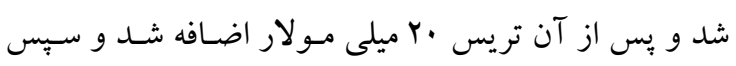

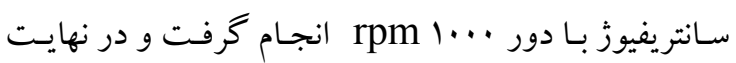
قسمت رويى حاوى DNA جدا گرديد (19). روش PCR

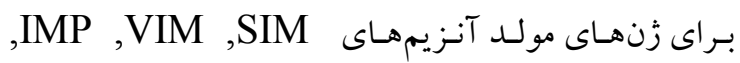
GIM ,KPC ,AmpC ,OXA48,SPM ايزولـهـــاى سـودوموناس آئروثرينسوزا توسـط بر ايمرهـاى

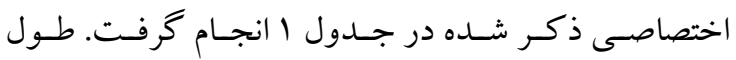
باندهاى مورد نظر بر اساس bp (جفت باز) مى لـاشد.
سانتى گر اد بليت ها انكوبه شده و نتايج خو انده شد. بـا توجـه

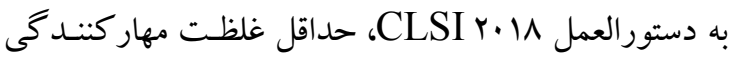

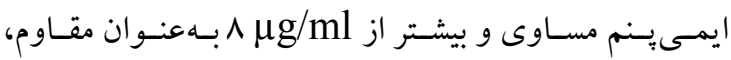

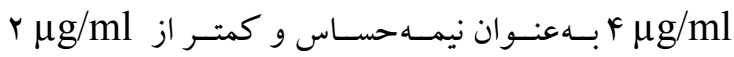
به بنوان حساس در نظر گرفته مىشود (IV).

تست CIM

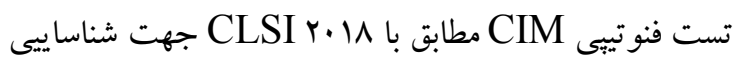
ايزولههاى مولد آنزيمهاى كارباينماز انجام شد (1) ) .

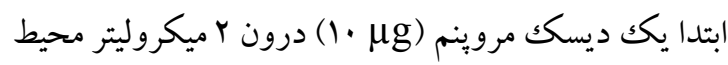

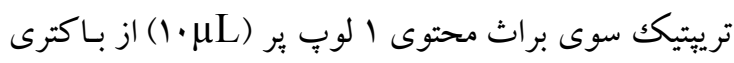

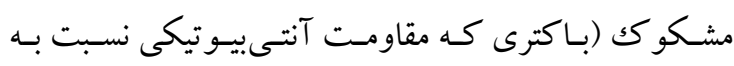

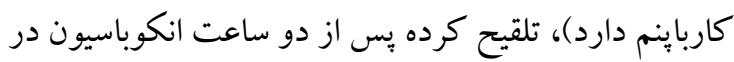

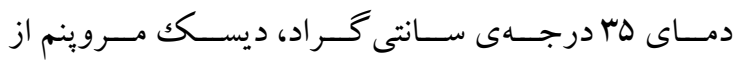

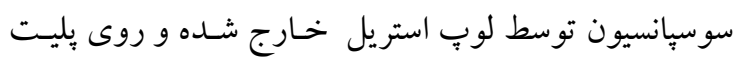

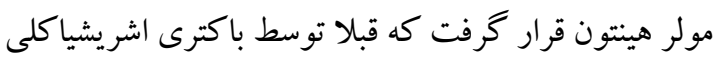
STCC 25922 بوده و به عنوان سويهى كنترل منفى مسىباشـد، كشـت داده شد. اين باكترى از موسسهى تحقيقاتى انستيتو ياستور كشـور

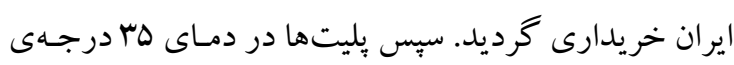

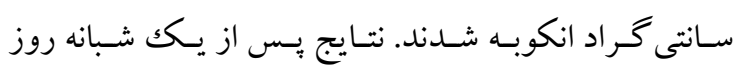

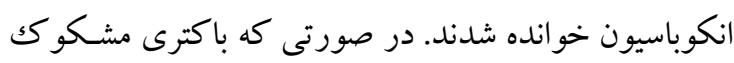
مولد آنزيم كاربإِماز باشد، مروينم توسط اين آنزيم، غير دير فعال شده و باكترى اشريشياكلى حساس بـه دليـل غيـر فعـال

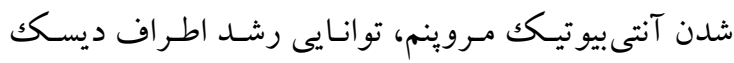

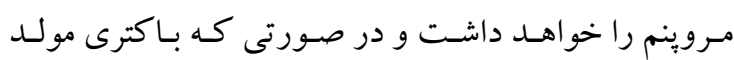

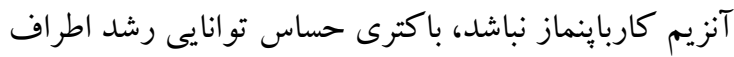

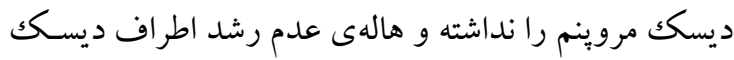

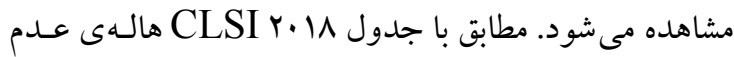

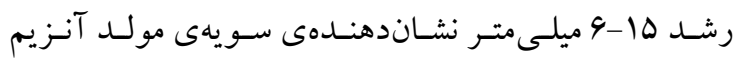

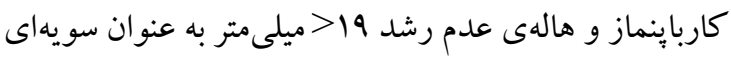

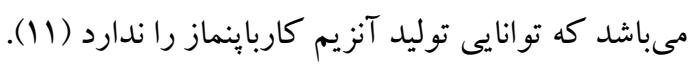


جدول ا: مشخصات ير ايمرهاى مورد استفاده در PCR

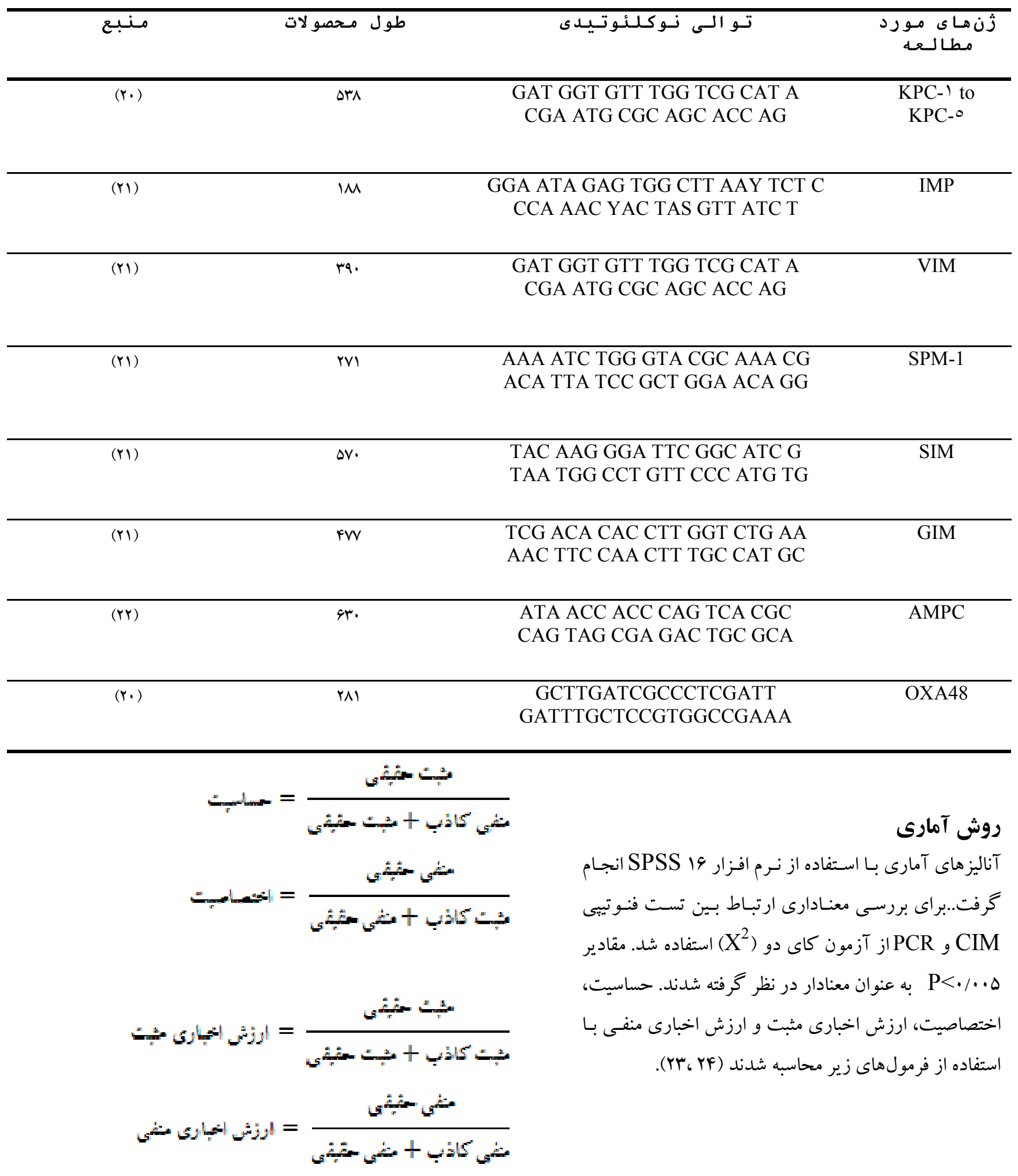


حساسيت آنتى بيوتيكى بر اسـاس دستور العمل CLSIY.

يافتهها

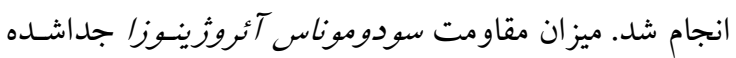
جمع آورى ايزولهها و تست حساسيت آنتىبيوتيكى: از بيماران بسترى در بيمارستان نسبت بـه آنتىبيوتيككهـاى تعداد ها لا باكترى سودوموناس آئروزينوزا /ز بيمارستانهاى إنى بررسى شده در نمودار اذكرشده است.

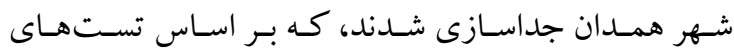
تشـخيص آزمايشـكاهى لو (

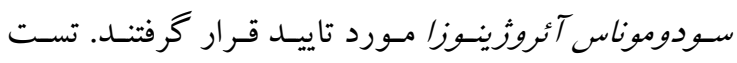
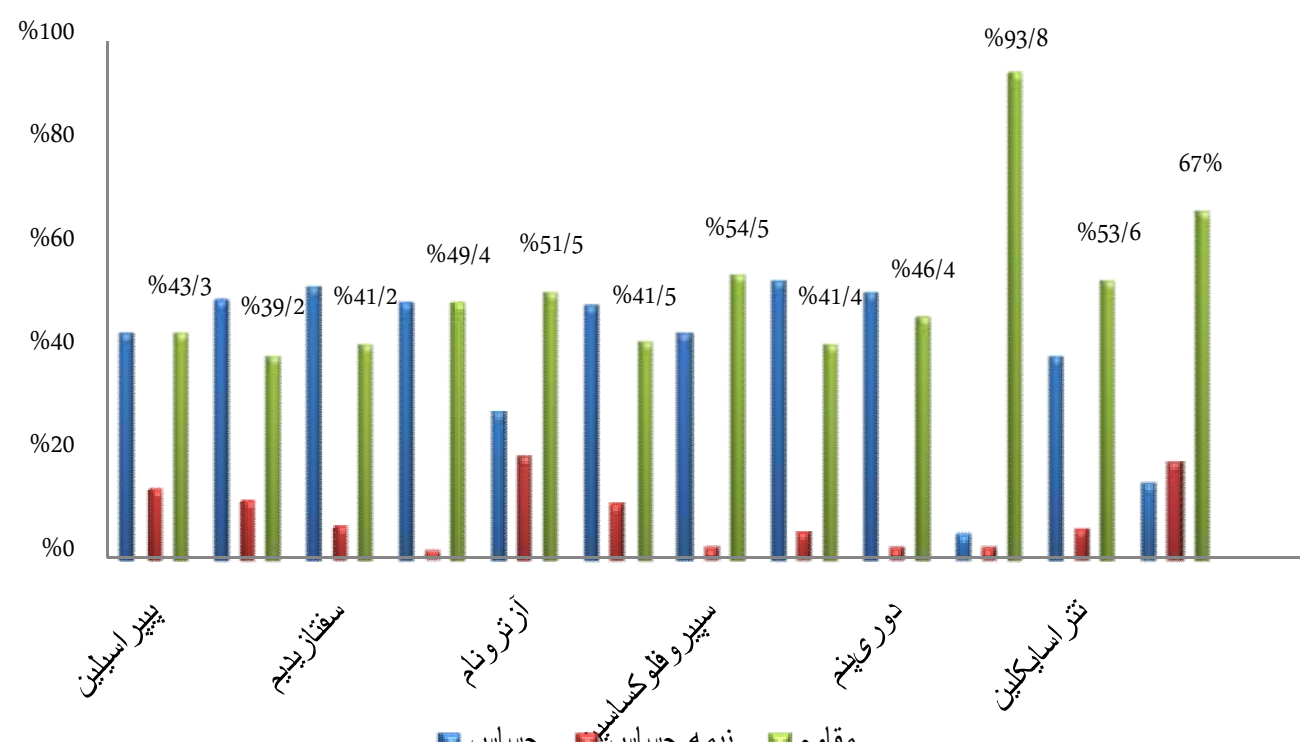

نمودار ا. نتايج مقاومت آنتىبيوتيكى ايزولههاى سودوموناس آئووثينوزا

بهنو ان نيمه حساس و كمتر از بg/ml ب بهعنو ان حساس در نظر كرفته مىشود.

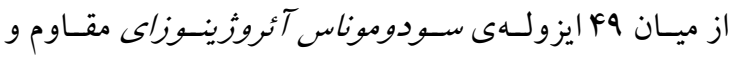

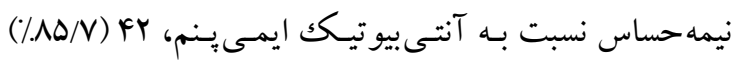

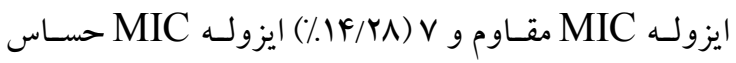

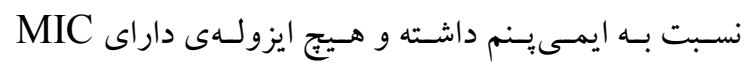
حدواسط وجود نداشت (نمودار r، تصوير (1). با توجه به نتايج نمودار ا، بيشترين ميزان مقاومت نسبت بـه

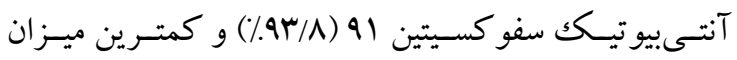

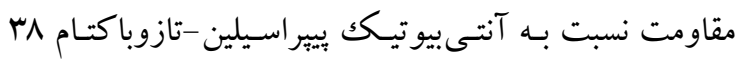

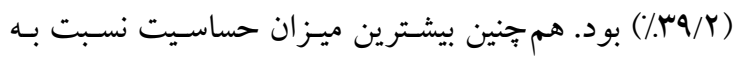

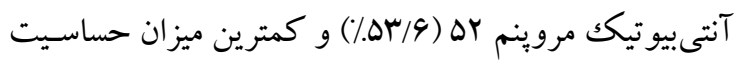

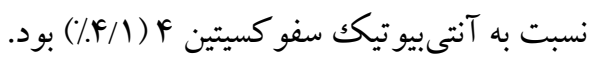

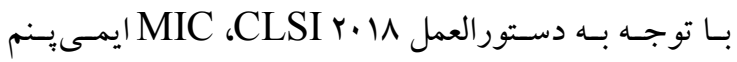

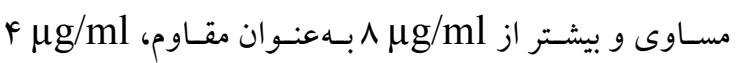




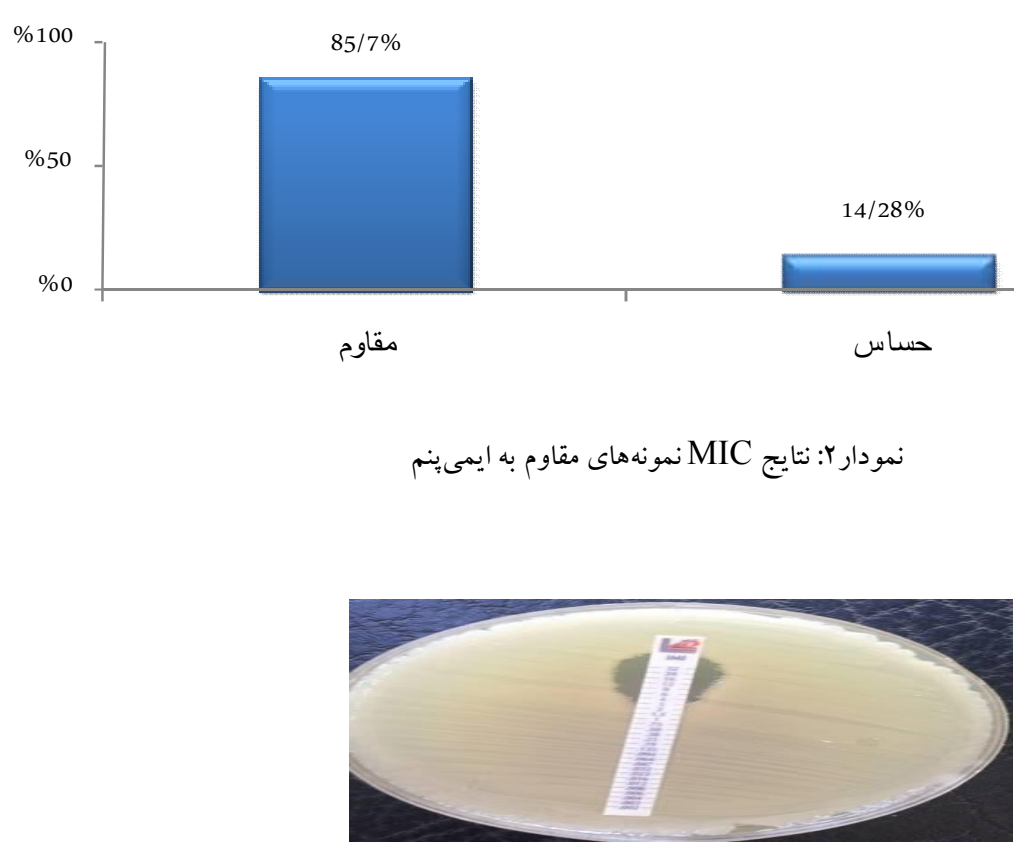

$$
\text { تصوير ا: نتايج تست MIC ايمىينم ايزولههاى سودوموناس آئروثينوزا }
$$

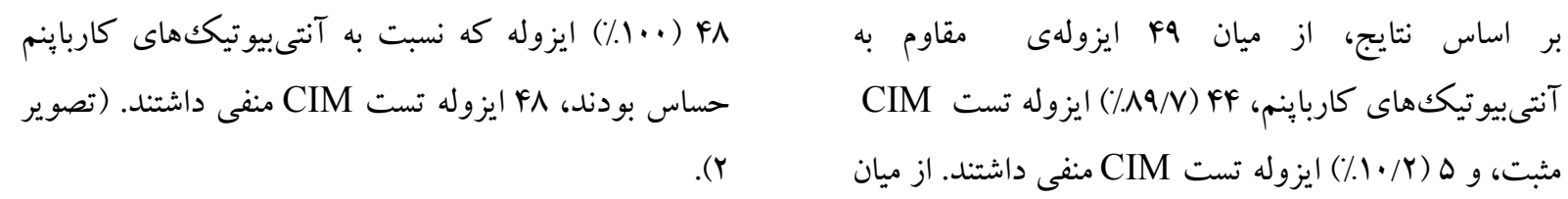

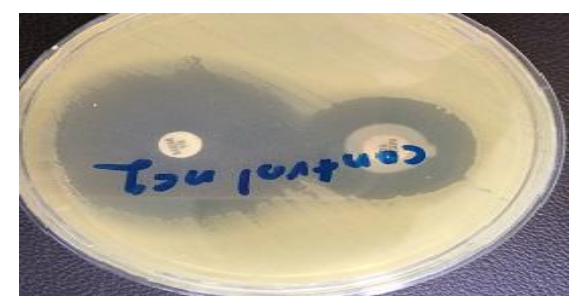

$r$

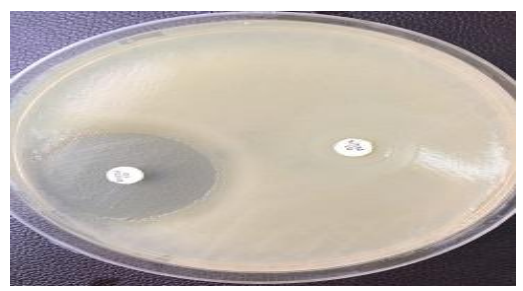

1

تصوير ז: نتايج حاصل از تست فنو تييى CIM ايزولههاى سودوموناس آئروزينوزا. ا: تست CIM مثبت ז: تست CIM منفى 


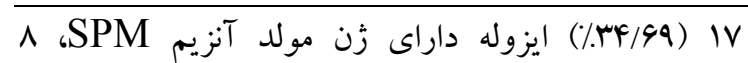

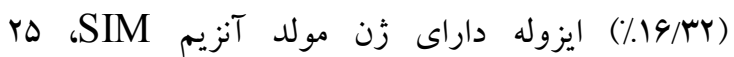

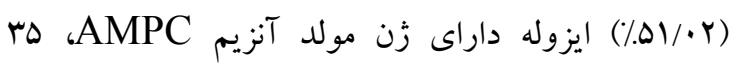

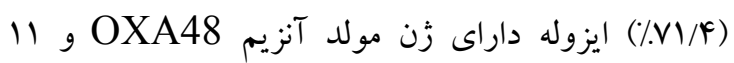

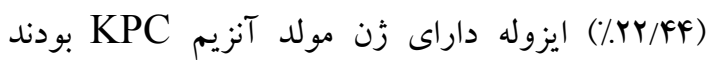

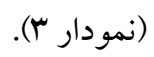

تعيين زنوتيبى سويههاى مولد آنزيمهاى كاربإينماز توسط از ميان V ايزولهى سودوموناس آئروزينوزا جداشده از

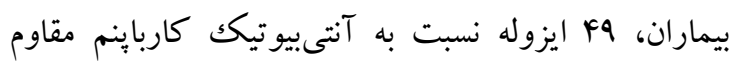

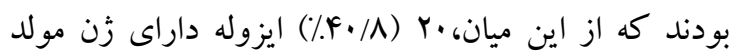

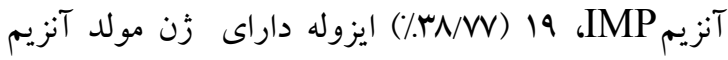

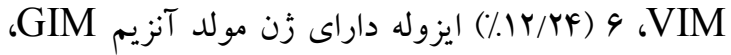

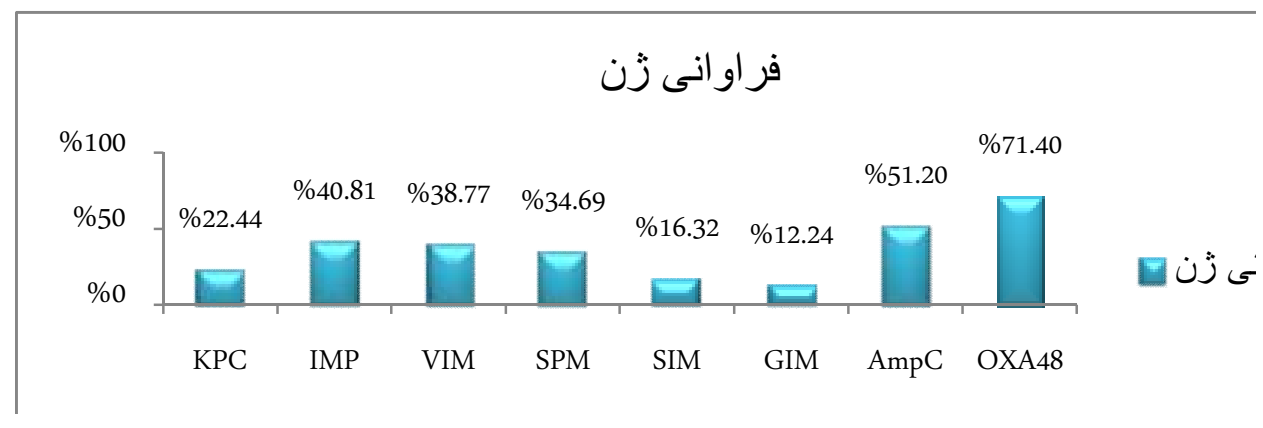

نمو دار "ا: فراوانى زُنهاى MBL و MPC ايزولههاى سودوموناس آثروثرينوزا

هr ايزولسهى مولــ آنـزيم AmpC و هץ ايزولـهى مولــد آنزيم OXA48، تست CIM به ترتيب قادر بـه شناسايى در r Y و سT ايزوله بود، كه حساسيت، اختصاصيت، ارزش

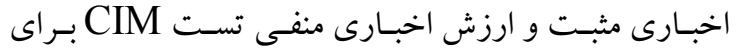

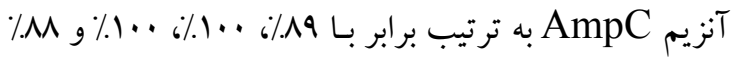

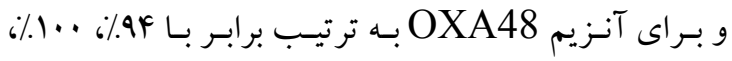

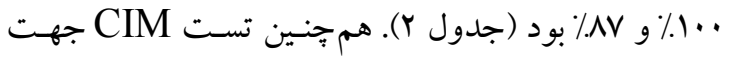

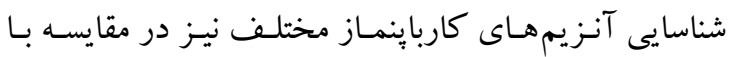

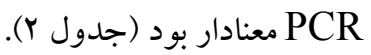

حساسـيت، اختصاصـيت، ارزش اخبــارى مثبــت و ارزش

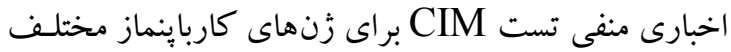

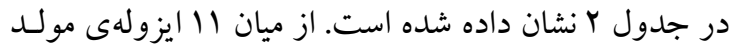
آنزيم KPC، ·r ايزولهى مولد آنزيم IMP، 19 ايزولهى

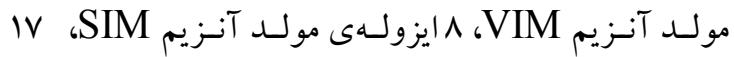

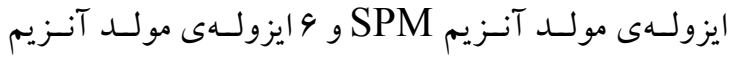

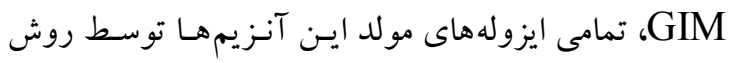
CIM

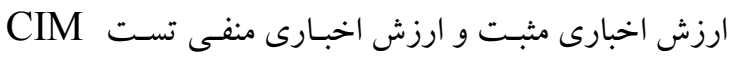

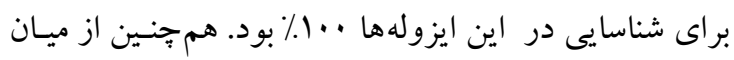




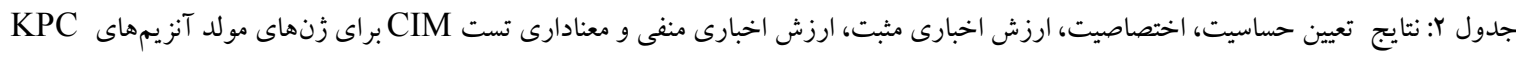
IMP P,VIM ,SPM ,SIM ,GIM ,AmpC

\begin{tabular}{|c|c|c|c|c|c|c|c|c|}
\hline $\begin{array}{c}\text { معنادارى } \\
\text { (P value) }\end{array}$ & ارزش اخبارى & ارزش اخبارى & اختصاصيت & حساسيت & منفى & مثبت CIM & PCR & كاربإينماز \\
\hline$P=\cdot /$. & $1 . . \%$ & $1 . . \%$ & $1 . . \%$ & $1 \ldots \%$ & . & 11 & 11 & $\mathrm{KPC}$ \\
\hline$P=\cdot / \cdot$ & $M \% \%$ & $1 . . \%$ & $1 \ldots \%$ & $\wedge ৭ \%$ & $r$ & YY & ro & AmpC \\
\hline$P=\cdot / \cdot$ & $\wedge \vee \%$ & $1 \ldots \%$ & $1 . . \%$ & $94 \%$ & $r$ & r & ro & OXA48 \\
\hline$P=\cdot / \cdot$ & $1 . . \%$ & $1 . . \%$ & $1 \ldots \%$ & $1 \ldots \%$ & . & $r$. & $r$. & IMP \\
\hline$P=\cdot / \cdot$ & $1 \ldots \%$ & $1 \ldots \%$ & $1 \ldots \%$ & $1 . . \%$ & . & 19 & 19 & VIM \\
\hline$P=\cdot / \cdot \cdot 1$ & $1 . . \%$ & $1 \ldots \%$ & $1 . . \%$ & $1 . . \%$ & . & $\wedge$ & $\wedge$ & SIM \\
\hline$P=. /$. & $1 . . \%$ & $1 . . \%$ & $1 . . \%$ & $1 \ldots \%$ & . & IV & IV & SPM \\
\hline$P=. /$. & $1 . . \%$ & $1 . . \%$ & $1 . . \%$ & $1 \ldots \%$ & . & 4 & 4 & GIM \\
\hline
\end{tabular}

كرفت، حساسيت و اختصاصيت روش CIM براى شناسايى

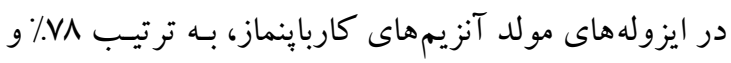

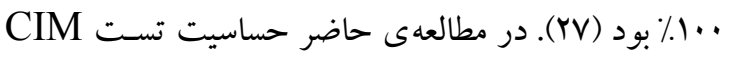
بالاتر از مطالعهى Aktas و همكاران در سال IV I ب. بـود و اختصاصيت در دو مطالعهى انجام شده مشـابه و برابـر . .. 1\% بــود. كــه ايــن تفــاوت در دو مطالعـهـ بــراى حساسـيت تسـتCIM, احتمـالا بـه دلايلـى از جملـه خطـاى نيـروى انسانى، شرايط محيط آزمايشگاهى و تجهيزات به كار رفته

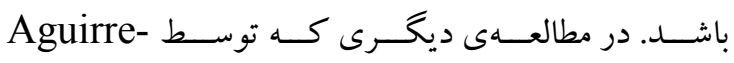

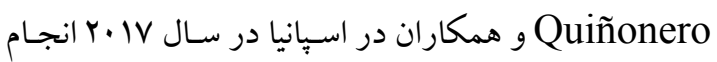
كرفـت، حساسـيت و اختصاصـيت روش CIM بـــراى شناسايى ايزوله هاى مولد آنزيمهـاى كاربإِنمـاز، بـه ترتيـب

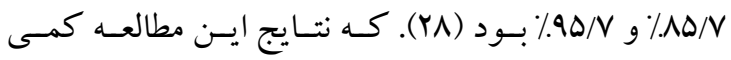
متفاوت با نتايج مطالعهى حاضر بود كه اختصاصيت نزديك

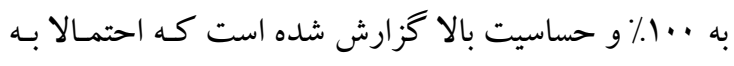
دليل تفاوت مناطق جغر افيـائى دو مطالعـهى انجـام گرفتـه و هم جنين تفاوت در الكوى مقاومت آنتىبيوتيكى سويههـاى دو مطالعه باشد كه از مكانيسـمى بـه جـز توليـد آنزيمهـاى كارباينماز براى مقاومت نسبت به آنتىبيو تيككهاى كارباينم استفاده كند. هم جنين در مطالعهاى كه توسط Bayraktar
در مطالعسهى حاضـر، تمـام سـويههـاى مولـد آنـزيمهــاى كارباينماز، تست CIM مثبت داشتند به جـز دو ايزوله كـه مولد آنزيم OXA48 بودند و سه ايزوله كـه مولـد آنزيم AmpC و حساسيت اين تست براى اين دو آنزيم بـه ترتيـب 9\&٪ و و

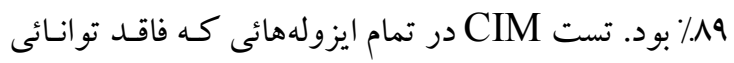

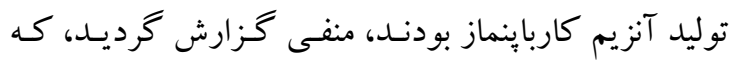
نشان دهندهى حساسيت .9\% و اختصاصيت .. 1\% اين تست مىباشد. از جمله مزاياى تست CIM سهولت در اجـراى ايـن روش، عدم نيازمندى به تجهيزات و مـواد گحرن قيمـت و هزينسى

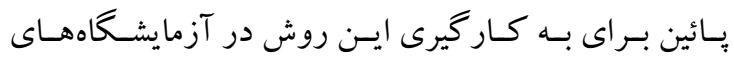

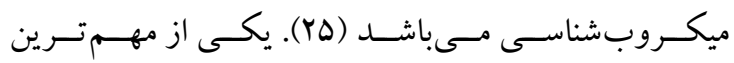
محدوديتهاى اين تست نيازمندى به انكوباسيون يكك شبانه روز بـراى خوانــن نتـايج قطـر هالـهى عـدم رشـد اطـراف

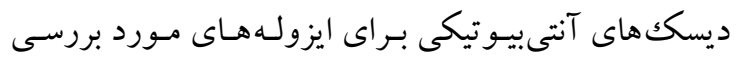
مىباشد(Y9). مطالعـات مختلفى جهـت تعيسين حساسـيت و اختصاصيت اين تست انجـام شـده اسـت. در مطالعهاى كـه توسط Aktas و همكاران در سـال IV •r در تركيـه انجـام 
ميزان حساسيت و اختصاصيت تغيير كند. همسو با مطالعهى ما، مطالعهى ديخرى كه توسط Suzuk و همكاران در سال

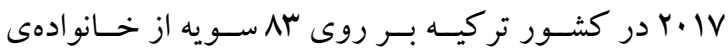
انتروباكترياسه جهت تعيين حساسيت و اختصاصيت روش CIM بـ اي آنزيم OXA-48 انجـام گرفـت، حساسيت

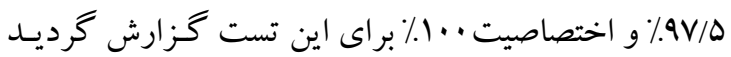

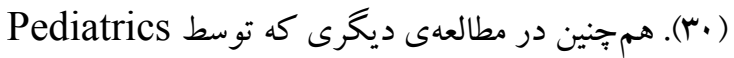

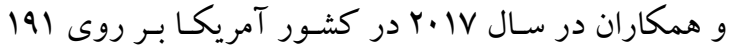
سويه از خانوادهى انتروباكترياسه انجام شد، حساسيت روش جهـت شناسـايى آنـزيمهــاى XIM

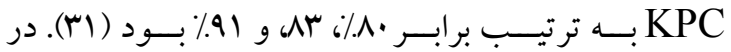
مطالعهى حاضـر حساسـيت روش CIM بـراى آنزيمهـاى

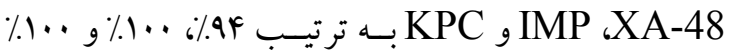
KPC از ردهى A آنزيمى و محدوديت تعـداد سـويههـاى

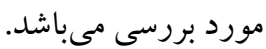

\section{نتيجه كيرى}

با توجه به نتايج حاصل از اين مطالعه ،به دليل حساسيت و

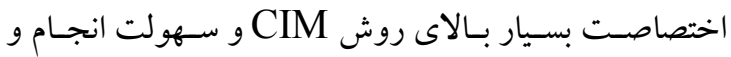

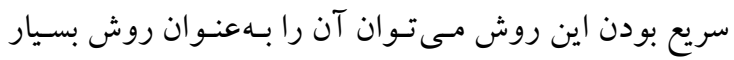
مناسبى براى تشخيص ايزوله هاى مولد آنزيمهاى كارباينماز در كمتـرين زمـان معرفى و در آزمايشـاههـاى بـالينى و تشخيص طبى مورد استفاده قرارداد.

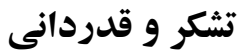

مقالهى حاضر حاصل طرح تحقيقـاتى مصـوب در معاونـت

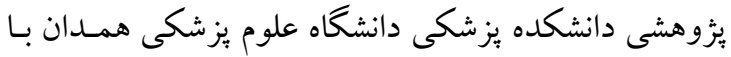

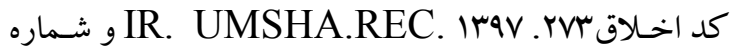

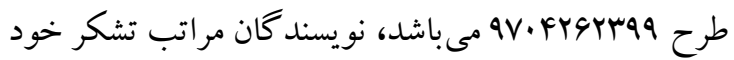
را از آن معاونت محترم ابراز مىدارند.
در تركيـه در ســال 19 ب انجـــام گرفــت حساسـيت و

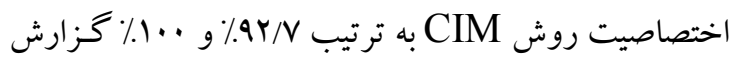
شد (YD). نتايج مطالعهى حاضر همسو با مطالعهى فوق بود كه به نظر مىرسد به دليل نزديكى دو منطقهى جغر افيائى و تشابه در الكوى مقـاومتى ايزولـهــاى دو منطقـه باشــــ ادر مطالعهاى كه توسط Lisiane Rech و همكاران در سال

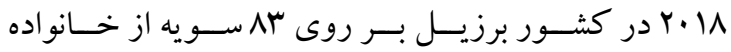
انتروباكترياسه انجـام شـد، حساسـيت و اختصاصيت تسـت CIM به تر تيـب C حساسـيت در مطالعهى Lisiane Rech و مطالعهى مـا تفاوت دارد، كه احتمالا به دليل تفاوت در تعداد سويههـاى مورد بررسى دو مطالعه باشد، كه در مطالعهى حاضـر تعـداد سويههاى كمترى مورد بررسى قرار گرفته است كه مى تواند بود كه اين تفاوت در ميزان حساسيت مسى توانـد احتمـالا بـهـ دليل تفاوت در تعداد سويههاى دو مطالعه و همجنين تفاوت

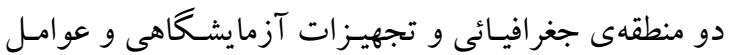

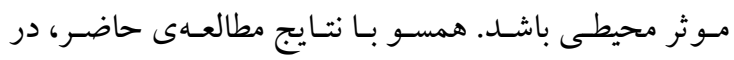

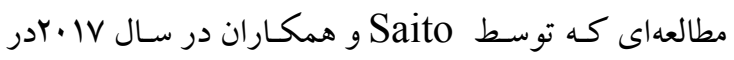
كشور زاين بر روى سبr سويه از خـانوادهى انتروباكترياسـه

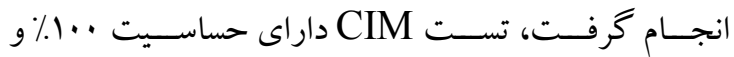
اختصاصيت /91/9 جهت شناسايى زنهاى KPC، IMP و OXA-48

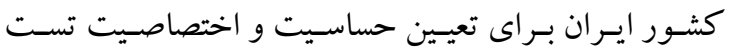

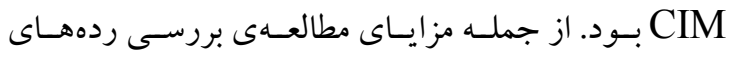
آنزيمى A-D از آنزيمهـاى كارباينمـاز بـود كـه در هـيجيج مطالعهاى تمام كلاسهاى آنزيمسى بررسى نشــه بودنــــ از

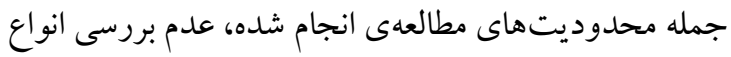

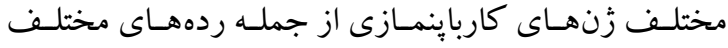

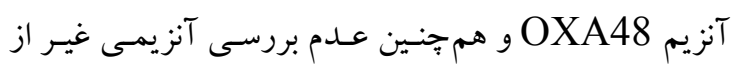




\section{Reference}

1. Potron Poirel L, Nordmann PJ. Emerging broad-spectrum resistance in Pseudomonas aeruginosa and Acinetobacter baumannii mechanisms and epidemiology. Int J Antimicrob Agents 2015;45:56885.

2. Wi YM, Greenwood-Quaintance KE, Schuetz AN, Ko KS, Peck KR, Song J-H, et al. Activity of ceftolozane-tazobactam against carbapenem-resistant, non-carbapenemase-producing pseudomonas aeruginosa and associated resistance mechanisms. Antimicrob Agents Chemother 2017;62:pii: e01970-17.

3. Poirel L, Nordmann P, Lagrutta E, Cleary T, Munoz-Price LS. Emergence of KPC-producing Pseudomonas aeruginosa in the United States. Antimicrob. Agents Chemother 2010;54:3072.

4. Hong DJ, Bae IK, Jang I-H, Jeong SH, Kang H-K, Lee KJI, et al. Epidemiology and characteristics of metallo- $\beta$-lactamase-producing Pseudomonas aeruginosa. Infect Chemother 2015;47: 97-81.

5. Castanheira M, Rhomberg PR, Flamm RK, Jones RNJAa, chemotherapy. Effect of the $\beta$-lactamase inhibitor vaborbactam combined with meropenem when tested against serine-carbapenemaseproducing enterobacteriaceae. Antimicrob Agents Chemother 2016;60:5454-8.

6. Öztürk H, Ozkirimli E, Özgür AJPo. Classification of Beta-lactamases and penicillin binding proteins using ligand-centric network models. PLos One 2015;10:e0117874.

7. Pathak P, Jaishi N, Yadav BK, Shah PKJM. Prevalence of extended spectrum beta lactamases (ESBL) and metallo beta lactamases (MBL) mediated resistance in gram negative bacterial pathogens. J Microbiol 2017;4:561-7.

8. Chika E, Charles E, Ifeanyichukwu I, Chigozie U ,Chika E, Carissa D, et al. Phenotypic detection of AmpC beta-lactamase among anal Pseudomonas aeruginosa isolates in a Nigerian abattoir. Archive Clin Microbiol 2016;7:1-5.

9. Walther-Rasmussen J, Hoiby N. OXA-type carbapenemases. J Antimicrob Chemother 2006;57:373-83.

10. McMullen AR, Yarbrough ML, Wallace MA, Shupe A, Burnham C-ADJCc. Evaluation of genotypic and phenotypic methods to detect carbapenemase production in Gram-negative bacilli. Clin Chem 2017;63:723-30.

11. Crowe A, Brenton L, Kingston M ,Jardine D, Waters MJJP. Comparison of the carbapenem inactivation method (CIM) and modified carbapenem inactivation method (mCIM) for the detection of carbapenemase-producing organisms. Pathology 2018;50:764-6.

12. Pierce VM, Simner PJ, Lonsway DR, Roe-Carpenter DE, Johnson JK, Brasso WB, et al. The modified carbapenem inactivation method (mCIM) for phenotypic detection of carbapenemase production among Enterobacteriaceae. J Clin Microbiol 2017;55:2321-33.

13. van der Zwaluw K, de Haan A, Pluister GN, Bootsma HJ, de Neeling AJ, Schouls LMJPO. The carbapenem inactivation method (CIM), a simple and low-cost alternative for the Carba NP test to assess phenotypic carbapenemase activity in gram-negative rods. Plos One 2015;10:e123690.

14. Galvani AA, Tukmechi AJRHC. Determination of the prevalence of metallo- $\beta$-lactamases producing Pseudomonas aeruginosa strains from clinical samples by imipenem-EDTA combination disk method in Mottahari and Emam Khomaini hospitals of Urmia. J Healthe Qual 2015;2:58-65.

15. Clinical and Laboratory Standards Institute. Performance standards for antimicrobial susceptibility testing, 28th ed. CLSI supplement M100S. CLSI, PA, 2018;38-40.

16. Jorgensen JH, Turnidge JD. Manual of Clinical Microbiology; Susceptibility test methods: dilution and disk diffusion methods. 11 ed nd. Mbio, 2015;1253-73.

17. Humphries RM, Hindler JA, Magnano P, Wong-Beringer A, Tibbetts R, Miller SA. Performance of ceftolozane-tazobactam Etest, MIC test strips and disk diffusion as compared to reference broth microdilution for beta-lactam resistant Pseudomonas aeruginosa isolates. J Clin Microbiol 2018;56:e01633-17.

18. Aguirre-Quiñonero A, Cano M, Gamal D, Calvo J, Martínez-Martínez L. Evaluation of the carbapenem inactivation method (CIM) for detecting carbapenemase activity in enterobacteria. 2017;88:214-8. 
19. Junior JCR, Tamanini R, Soares BF, de Oliveira AM, de Godoi Silva F, da Silva FF, et al. Efficiency of boiling and four other methods for genomic DNA extraction of deteriorating sporeforming bacteria from milk. Semin Cienc Agrar 2016;37:3069-78.

20. Dallenne C, Da Costa A, Decre D, Favier C, Arlet G. Development of a set of multiplex PCR assays for the detection of genes encoding important beta-lactamases in Enterobacteriaceae. J Antimicrob Chemother 2010:65:490-5.

21. Wang TH, Leu YS, Wang NY, Liu CP, Yan TR. Prevalence of different carbapenemase genes among carbapenem-resistant Acinetobacter baumannii blood isolates in Taiwan. Antimicrob Resist Infect Control 2018;7:2-8.

22. Schill F, Abdulmawjood A, Klein G, Reich F. Prevalence and characterization of extendedspectrum $\beta$-lactamase (ESBL) and AmpC $\beta$-lactamase producing Enterobacteriaceae in fresh pork meat at processing level in Germany. J Food Microbiol 2017;257:58-66.

23. Baratloo A, Hosseini M, Negida A, El Ashal G. Part 1: Simple Definition and Calculation of Accuracy, Sensitivity and Specificity. Emerg (Tehran) 2015;3:48-9.

24. Safari S, Baratloo A, Elfil M, Negida A. Evidence Based Emergency Medicine Part 2: Positive and negative predictive values of diagnostic tests. Emerg (Tehran) 2015;3:87-8.

25. Bayraktar B, Barış A, Malkoçoğlu G, Erdemir D, Kına NJMDR. Comparison of carba NP-direct, carbapenem inactivation method, and $\beta$-CARBA tests for detection of carbapenemase production in Enterobacteriaceae. Microb Drug Resist 2019;25:97-102.

26. Kuchibiro T, Komatsu M, Yamasaki K, Nakamura T, Nishio H, Nishi I, et al. Evaluation of the modified carbapenem inactivation method for the detection of carbapenemase-producing Enterobacteriaceae. J Infect Chemother 2018;24:262-6.

27. Aktas E, Malkocoglu G, Otlu B, Copur Cicek A, Kulah C, Comert F, et al. Evaluation of the carbapenem inactivation method for detection of carbapenemase-producing gram-negative bacteria in comparison with the rapidec carba NP. Mi Microb Drug Resist 2017;23:457-61.

28. Aguirre-Quiñonero A, Cano M, Gamal D, Calvo J, Martínez-Martínez LJDm, disease i. Evaluation of the carbapenem inactivation method (CIM) for detecting carbapenemase activity in enterobacteria. Diagn Microbiol Infect Dis 2017;88:214-8.

29. Pancotto LR, Nodari CS, Rozales FP, Soldi T, Siqueira CG, Freitas AL, et al. Performance of rapid tests for carbapenemase detection among Brazilian Enterobacteriaceae isolates. Braz J Microbiol 2018;49:914-8.

30. Yildiz SS, Kaskatepe B, Avcikucuk H, Ozturk S. Performance of CarbaNP and CIM tests in OXA-48 carbapenemase-producing Enterobacteriaceae. Acta Microbiol Immunol Hung 2017;64:9-16. 31. Tamma PD, Opene BN, Gluck A, Chambers KK, Carroll KC, Simner PJ. Comparison of 11 phenotypic assays for accurate detection of carbapenemase-producing Enterobacteriaceae. J Clin Microbiol 2017;55:1046-55.

32. Saito K, Nakano R, Suzuki Y, Nakano A, Ogawa Y, YonekawaS, et al. Suitability of carbapenem inactivation method (CIM) for detection of IMP metallo- $\beta$-lactamase-producing Enterobacteriaceae. J Clin Microbiol 2017;55:1220-2.

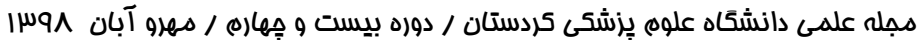

